Original Research

\title{
Suitability of Steel Making Slag as a Construction Material Resource
}

Lucy V. Fisher ${ }^{1}$, Andrew R. Barron ${ }^{1,2,3,4, *}$

1. Energy Safety Research Institute (ESRI), Swansea University, Bay Campus, Swansea SA1 8EN, UK; E-Mails: 821138@swansea.ac.uk; a.r.barron@swansea.ac.uk

2. Institute of Resilience, Rice University, Houston, Texas 77005, USA

3. Faculty of Engineering, Universiti Teknologi Brunei, Brunei Darussalam

4. Arizona Institute of Resilience (ARI), University of Arizona, Tucson, Arizona 85719, USA

* Correspondence: Andrew R. Barron; E-Mails: a.r.barron@swansea.ac.uk

Academic Editor: Jorge de Brito

Special Issue: Wastes, Residues and Byproducts for the Production of Construction Materials

Recent Progress in Materials

2021, volume 3, issue 3

doi:10.21926/rpm.2103028
Received: February 24, 2021

Accepted: July 07, 2021

Published: July 16, 2021

\begin{abstract}
One of the largest problems facing the steelmaking industry is the high amount of waste currently produced and the low amount of waste that is currently recycled. This study aims to look at the suitability of 3 different samples of basic oxygen steelmaking (BOS) slag as a construction material, in concert with their carbon capture capacity. Characterization by scanning electron microscopy (SEM), X-ray diffraction (XRD), inductively coupled plasma spectroscopy (ICP), X-ray fluorescence (XRF), $\mathrm{CO}_{2}$ adsorption analysis, and thermogravimetric analysis (TGA) demonstrated that these BOS slags were found to have several favorable characteristics making them suitable for reuse as construction material.
\end{abstract}

\section{Keywords}

Steelmaking; slag; cement; characterization; recycling

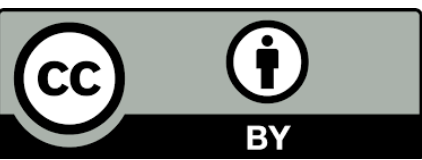

(C) 2021 by the author. This is an open access article distributed under the conditions of the Creative Commons by Attribution License, which permits unrestricted use, distribution, and reproduction in any medium or format, provided the original work is correctly cited. 


\section{Introduction}

During the steelmaking process, various slags are produced as by-products of the steelmaking process [1]. The first stage of the production of steel is blast furnace (BF) steelmaking, in which raw iron ore is converted into pig iron. The pig iron must be refined by either basic oxygen steelmaking (BOS) or electric arc furnace (EAF) steelmaking. Both of these processes produce slags as a byproduct, which is a mainly non-metallic by-product that is made up of silicates, alumina silicates, calcium aluminum silicates, iron oxides, and other crystalline compounds [2]. Around 20 million tons of slag from the steel industry is produced annually in Europe, half of which is BOS slag [3], and there is a significant demand to find a way to recycle the waste to protect the environment and make sure that the steel industry is environmentally sustainable [2].

In the production of concrete, aggregate makes up about $70 \%$ of what is added into the cement mix. Traditionally natural sand has been used to make up the aggregate in cement. Yet, natural sand is very costly and is dredged up from riverbeds, which can be damaging to the environment. For example, excavating beach sand has been forbidden in inland areas of Japan [4]. Fortunately, several decades ago, scientists began to consider recycling waste materials to replace aggregate in concrete [4]. This research began in the 1980s with scientists' trialing whether or not cementitious and pozzolanic by-products such as fly ash, granulated blast-furnace slag, and condensed silica fume could be added as aggregate to create concrete. Several separate experiments reported that the addition of blast furnace slag as aggregate to cement matched the strength of cement with natural sand as aggregate. In some cases, the blast furnace slag cement was stronger than the natural sand cement. The increase in strength was generally observed about 14 days after the initial mixing; however, it was suggested that with higher calcium content, there was a higher rate of strength gain [5]. Carvalho et al. looked at the influence of adding BOS slag as aggregate in addition to BF slag [6]. It was observed that initially, after a period of 28 days, the mechanical strength increased to a peak at $25 \%$ strength gain; however, after 91 days, the mechanical strength gain decreased to $5 \%$. This was compared to blast furnace cement that only used blast furnace aggregate. The use of BOS slag also has economic and environmental benefits.

The properties required for aggregate vary by the intended final use of the concrete; however, generally, the aggregate must be a clean, hard, and durable particle free from any chemical that may affect the chemical composition of the concrete and cause failure [7]. Compared to traditional aggregate, e.g., granite and basalt steelmaking slag have comparable properties and, in some cases, more favorable properties. The density of the BOS slag is greater than that of both basalt and granite. BOS slag also has a higher Los Angeles abrasion value than granite and a better impact value. Abrasion resistance and impact resistance are favorable properties in making durable concrete [8]. Electric arc furnace (EAF) slag has been shown to provide shielding properties against gamma-ray radiation. EAF concrete provides superior shielding properties compared to traditional concrete due to the high iron oxide content [9]. Finally, BOS slag has a very similar iron oxide content to EAF slag [8].

Utilizing BOS slag in the cement industry is a promising way to reduce the waste from the steelmaking industry. This study aims to characterize 3 different samples of local steelmaking slag to assess if they would be suitable for further study as a construction material, in particular in concert with their capacity for carbon sequestration [10]. 


\section{Materials and Methods}

\subsection{Slag}

Three different samples of basic oxygen steelmaking (BOS) slag were used in the study and were collected from Tata Steel, Port Talbot, South Wales, SA13 2NG. On site, BOS slag is sorted into two regimes using vibrating screens $(45 \mathrm{~mm}$ and 5-10 $\mathrm{mm}$ ) before being stored as piles (Figure 1). The measurement in the slag description refers to the average diameter of a piece of slag. Samples were taken from two piles of $45 \mathrm{~mm}$ slag (Samples A and B), and a sample was taken from the $5-10 \mathrm{~mm}$ pile (Sample C). The slag is officially designated as a waste product in the Tata Steel environmental permit [11].

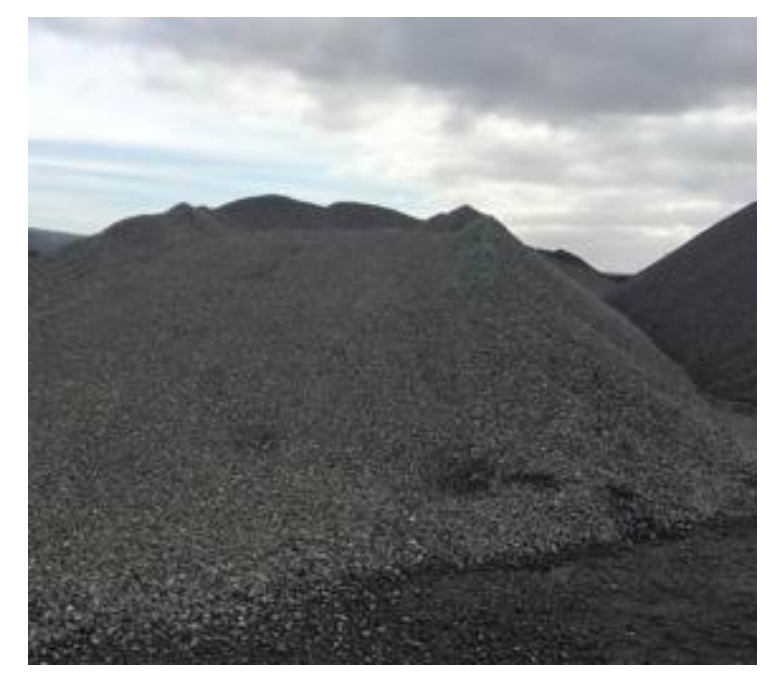

Figure 1 Photographs of basic oxygen steelmaking (BOS) slag pile from which sample A was collected at Tata Steel, Port Talbot on 20 $0^{\text {th }}$ October 2017.

\subsection{Methodology}

\subsubsection{Slag Sample Crushing}

The slag sample to be crushed was placed into a low-density polyethylene (LDPE) plastic bag with a zip closure. The bag was then placed inside another LDPE bag, and this process was repeated 5 times. The bags were used to make sure that parts of the slag sample did not get propelled out of the crushing area. The bags were then placed on a piece of cardboard and then placed on a wooden workbench. The cardboard was used to prevent damage to the wooden workbench. A $0.45 \mathrm{~kg}$ hammer was then used to crush the slag sample. Once enough pieces of slag had been broken off in a smaller size fraction, they were placed into a pestle and mortar to be crushed into a powder suitable for XRD and SEM analysis.

\subsubsection{Characterization}

Scanning electron microscopy with energy dispersive X-ray spectroscopy (SEM-EDX) analysis was performed using a Hitachi TM3030 Plus Tabletop Microscope equipped with an Oxford Instruments $X$ Stream 2 EDX detector. EDX analysis was performed using Oxford instruments Aztec one software. 
X-ray Diffraction (XRD) was performed using a Bruker D8 Discover diffractometer equipped with a non-monochromatic $\mathrm{Cu}-\mathrm{K}_{\alpha}$ source. The XRD was performed over a $2 \theta$ range of $20^{\circ}-80^{\circ}$, a time step of 1.5 seconds and an increment of $0.02^{\circ}$, and Diffrac.EVA software was used to analyze the data. X-ray fluorescence (XRF) was performed using a Malvern Panalytical Axios Fast XRF, performed by the basic oxygen furnace laboratories at Tata Steel Port Talbot. A Perkin Elmer Optima 8300 machine was used for Inductively Coupled Plasma Optical Emission Spectroscopy (ICP-OES) and the Syngistix for ICP computer program was used to analyze the data. The ICP-OES analysis was performed by Harbourside Laboratories at Tata Steel, Port Talbot. Thermogravimetric analysis (TGA) was performed using a TA Instruments SDT Q600. For each analysis, the sample was heated up to $700{ }^{\circ} \mathrm{C}$ to decompose the sample under argon and release any $\mathrm{CO}_{2}$ that had previously been absorbed. The TGA instrument was then allowed to cool to room temperature, and the sample was then exposed to wet $\mathrm{CO}_{2}$ at a flow rate of $80 \mathrm{~mL} / \mathrm{min}$ for 4 hours. Wet $\mathrm{CO}_{2}$ was produced by bubbling $\mathrm{CO}_{2}$ through a glass bubbler filled with distilled water. The sample was then heated to $100{ }^{\circ} \mathrm{C}$ and held for 5 minutes to remove any mass gain that may have been caused by water in the wet $\mathrm{CO}_{2}$ flow. An accurate representation of the amount of $\mathrm{CO}_{2}$ absorbed could be acquired. $\mathrm{CO}_{2}$ gas sorption analysis was completed using a Quantachrome iSorb HP1 high-pressure gas sorption analyzer. Before analysis, each sample was degassed under vacuum for 4 hours at $180{ }^{\circ} \mathrm{C}$. Each $\mathrm{CO}_{2}$ isotherm was conducted at $83{ }^{\circ} \mathrm{C}$ to maximize $\mathrm{CO}_{2}$ uptake [10]. For each $\mathrm{CO}_{2}$ isotherm, 19 data points were collected from 0 to 10 bar.

\section{Results}

\subsection{Slag Morphology}

The morphology of BOS slag is illustrated with the photographs that can be seen in Figure 2. The slag had a very fine-grained, porous structure containing small crystals that would only be visible with the use of a microscope.
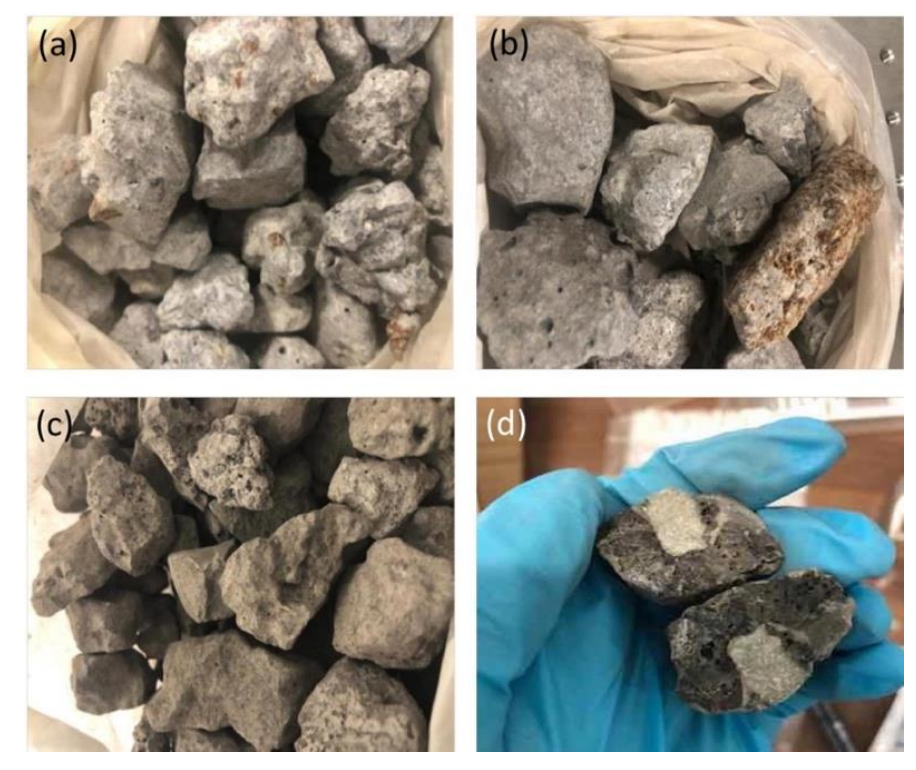

Figure 2 Photographs of basic oxygen steelmaking (BOS) slag samples: (a) sample $A$, (b) sample $B(c)$ sample $C$, and (d) a piece of sample A slag illustrating the presence of a free lime pocket. All sample were obtained from Tata Steel, Port Talbot on 20 $0^{\text {th }}$ October 2017. 
The samples have a very angular and rough surface. This is a favorable property for BOS slag's use as aggregate, as it can create a better bond between the surface of the aggregate and the cement paste [7]. It was also observed that some samples of slag had a porphyritic texture in which large crystals could be seen surrounded by a finer grained structure. It can be visibly seen in Figure $2 \mathrm{~d}$ that there is a large area of free lime $(\mathrm{CaO})$ shown by the light grey included area in the sample.

The surface morphologies of the BOS slags were analyzed by scanning electron microscopy (SEM), while the near surface elemental composition was determined by EDX analysis. Figure 3 shows images of the three different samples of steelmaking slag. A representative EDX spectrum is shown in Figure 4.
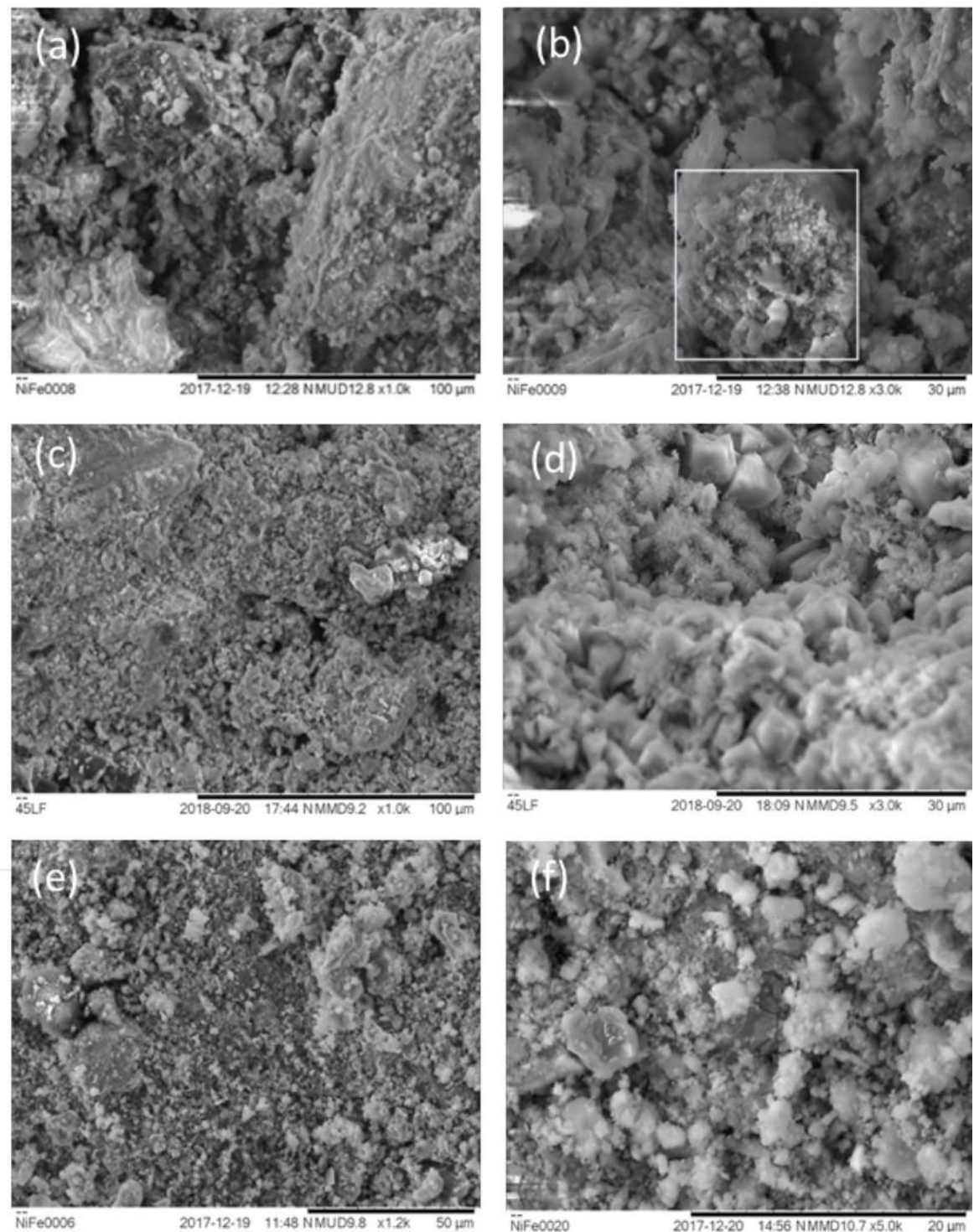

Figure 3 Scanning electron microscopy images of basic oxygen steelmaking (BOS) slag samples: sample $A(a$ and $b)$, sample $B$ ( $c$ and $d$ ), and sample $C$ (e and f). Scale bars are $100 \mu \mathrm{m}$ ( $\mathrm{a}$ and $\mathrm{c}$ ), $30 \mu \mathrm{m}$ ( $\mathrm{b}$ and d), $50 \mu \mathrm{m}$ (e), and $20 \mu \mathrm{m}$ (f). The highlighted box in (b) is a large particle, whose composition is determined as iron by EDX analysis (shown in Figure 3). 


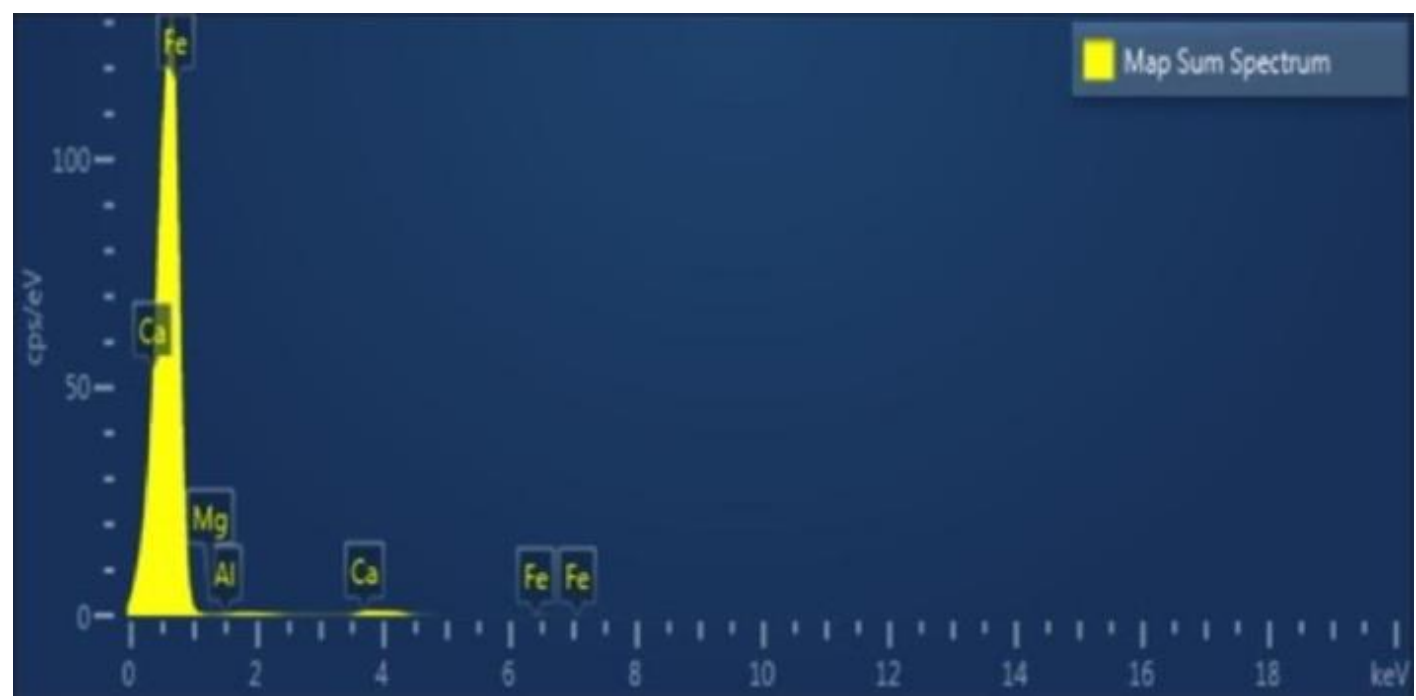

Figure 4 Energy dispersive X-ray (EDX) measurement of the large particle in the highlighted region of the SEM image (Figure $3 b$ ) of sample $A$.

\subsection{Elemental Analysis}

Table 1 The chemical composition (\%) of basic oxygen steelmaking (BOS) slag determined by X-ray fluorescence (XRF).

\begin{tabular}{cccc}
\hline Component & Sample A & $\begin{array}{c}\text { Atomic concentration (\%) } \\
\text { Sample B }\end{array}$ & Sample C \\
\hline $\mathrm{S}$ & 0.050 & 0.049 & 0.047 \\
$\mathrm{Total} \mathrm{Fe}$ & 13.25 & 24.54 & 19.40 \\
$\mathrm{CaO}$ & 17.43 & 39.38 & 42.84 \\
$\mathrm{C}$ & 0.878 & 0.063 & 0.106 \\
$\mathrm{SiO}_{2}$ & 5.02 & 11.79 & 14.82 \\
$\mathrm{Al}_{2} \mathrm{O}_{3}$ & 49.19 & 2.73 & 2.75 \\
$\mathrm{MgO}_{\mathrm{MnO}}$ & 4.29 & 7.38 & 7.50 \\
$\mathrm{P}_{2} \mathrm{O}_{5}$ & 4.78 & 2.57 & 2.54 \\
$\mathrm{TiO}_{2}$ & 0.16 & 1.27 & 1.34 \\
$\mathrm{~V}_{2} \mathrm{O}_{5}$ & 0.39 & 0.67 & 0.69 \\
$\mathrm{Total}_{\text {Basicity }}$ & 0.112 & 0.547 & 0.700 \\
& 99 & 99 & 99 \\
& 3.47 & 3.34 & 2.89 \\
\hline
\end{tabular}

\subsection{Crystalline Phase Determination}

The crystal phase composition of finely ground samples of the three BOS slag samples was determined by X-ray diffraction (Figure 5). All the observed peaks were fitted to phases based upon the COD files for $\mathrm{Al}_{2} \mathrm{O}_{3}$ corundum (9009671), $\mathrm{CaO}$ lime (1011094), $\mathrm{CaCO}_{3}$ calcite (9009668), $\mathrm{Ca}_{3} \mathrm{SiO}_{5}$ (1540704), $\beta-\mathrm{Ca}_{2} \mathrm{SiO}_{4}$ (2310924), $\gamma-\mathrm{Ca}_{2} \mathrm{SiO}_{4}$ (2310675), $\mathrm{Ca}_{2} \mathrm{O}_{5} \mathrm{Fe}_{2}$ (9014369), $\mathrm{Ca}_{4} \mathrm{Al}_{2} \mathrm{Fe}_{2} \mathrm{O}_{10}$ (1008124), $\mathrm{Cr}_{2} \mathrm{O}_{3}$ eskolaite (9016427), $\mathrm{Fe}_{0.944} \mathrm{O}$ wüstite (9011168), $\mathrm{Fe}_{0.902} \mathrm{O}$ (2106936), $\mathrm{MgO}$ periclase (1000053), $\mathrm{Mn}_{2} \mathrm{O}_{3}$ bixbyite (9014248), $\mathrm{SiO}_{2}$ quartz (9013321), $\mathrm{SiO}_{2}$ (4124053), $\alpha-\mathrm{SiO}_{2}$ quartz (1011097), $\mathrm{Ti}_{2} \mathrm{O}_{3}$ (1527090), $\mathrm{TiO}$ (1536851), $\mathrm{V}_{4} \mathrm{O}_{7}$ (1528714), $\mathrm{Ca}(\mathrm{OH})_{2}$ (1008781) and $\mathrm{CaCO}_{3}$ (9016705). 
Table 2 The chemical composition (\%) of basic oxygen steelmaking (BOS) slag determined by inductively coupled plasma optical emission spectroscopy (ICP-OES).

\begin{tabular}{cccc}
\hline Element & \multicolumn{3}{c}{ Atomic concentration (\%) } \\
& Sample A & Sample B & Sample C \\
\hline $\mathrm{Al}$ & 1.15 & 0.72 & 0.90 \\
$\mathrm{As}$ & $<0.001$ & $<0.001$ & $<0.001$ \\
$\mathrm{~B}$ & $<0.001$ & $<0.001$ & $<0.001$ \\
$\mathrm{Ba}$ & 0.015 & 0.019 & 0.026 \\
$\mathrm{Ca}$ & 32.0 & 31.1 & 31.7 \\
$\mathrm{Cd}$ & $<0.001$ & $<0.001$ & $<0.001$ \\
$\mathrm{Co}$ & $<0.001$ & $<0.001$ & $<0.001$ \\
$\mathrm{Cr}$ & 0.072 & 0.090 & 0.069 \\
$\mathrm{Cu}$ & $<0.001$ & $<0.001$ & $<0.001$ \\
$\mathrm{Fe}$ & 15.5 & 21.0 & 17.0 \\
$\mathrm{~K}$ & 0.008 & 0.005 & 0.005 \\
$\mathrm{Mg}$ & 5.38 & 5.57 & 5.60 \\
$\mathrm{Mn}$ & 1.49 & 1.30 & 1.63 \\
$\mathrm{Mo}$ & $<0.001$ & $<0.001$ & $<0.001$ \\
$\mathrm{Na}$ & 0.026 & 0.019 & 0.021 \\
$\mathrm{NI}$ & 0.001 & $<0.001$ & $<0.001$ \\
$\mathrm{~Pb}$ & $<0.001$ & 0.001 & $<0.001$ \\
$\mathrm{Sb}$ & 0.001 & 0.001 & 0.001 \\
$\mathrm{~V}$ & 0.28 & 0.34 & 0.64 \\
$\mathrm{Zn}$ & $<0.001$ & $<0.001$ & $<0.001$ \\
\hline
\end{tabular}

The elemental composition of the BOS slag samples was determined by X-ray fluorescence (Table 1) and inductively coupled plasma optical emission spectroscopy (Table 2). From Table 1, it can be seen that the total Fe content of the slag is considerably different in each of the slags. The concentration of total Fe ranged from 13.25\%-24.54\%.

\section{4 $\mathrm{CO}_{2}$ Adsorption Capacity}

Table 3 The $\mathrm{CO}_{2}$ adsorption capacity (mmol/g) of basic oxygen steelmaking (BOS) slag determined by thermogravimetric analysis (TGA) and gas adsorption using iSorb.

\begin{tabular}{cccc}
\hline & \multicolumn{3}{c}{$\mathrm{CO}_{2}$ Adsorption Capacity (mmol/g) } \\
& Sample A & Sample B & Sample C \\
\hline TGA (1 bar) & 0.077 & 0.139 & 0.264 \\
iSorb (1 bar) & 0.016 & 0.005 & 0.016 \\
iSorb (10 bar) & 0.041 & 0.034 & 0.034 \\
\hline
\end{tabular}

The $\mathrm{CO}_{2}$ uptake capacity for the as received slag samples was measured as a function of pressure using an iSorb HP1 high pressure gas sorption analyzer. The samples were preheated to $180{ }^{\circ} \mathrm{C}$ to desorb any water but would not desorb any adsorbed atmospheric $\mathrm{CO}_{2}$ that occurred during the open-air storage of the slags (c.f., Figure 1). Each $\mathrm{CO}_{2}$ isotherm was conducted at $83^{\circ} \mathrm{C}$ to maximize $\mathrm{CO}_{2}$ uptake [10]. For each $\mathrm{CO}_{2}$ isotherm, 19 data points were collected from 0 to 10 bar. A 
representative plot of the pressure dependent adsorption is shown in Figure 6 . The uptake capacity ( $\mathrm{mmol} / \mathrm{g}$ ) for each slag is summarized in Table 3.
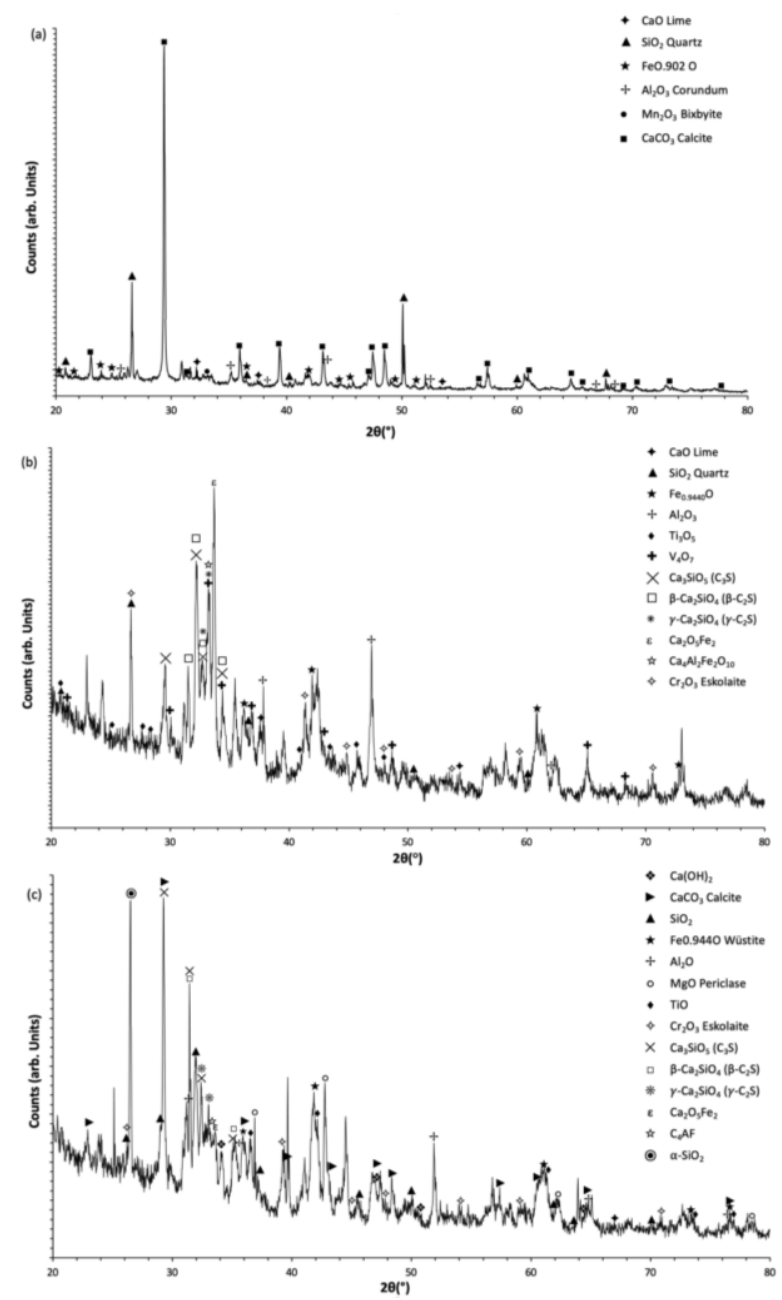

Figure $5 \mathrm{X}$-ray diffraction with peak assignment of basic oxygen steelmaking (BOS) slag: sample $A(a)$, sample B (b), and sample C (c).

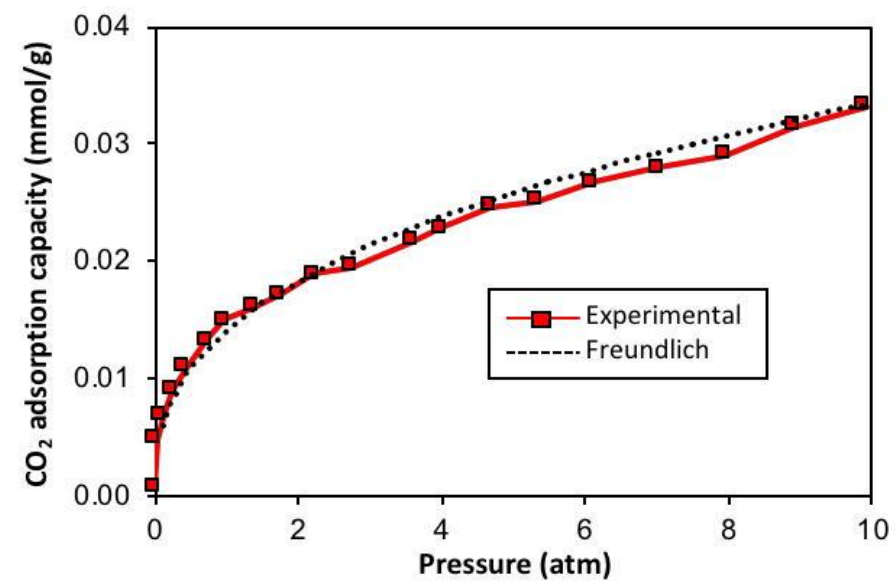

Figure 6 iSorb plot of dry $\mathrm{CO}_{2}$ adsorption capacity $\left(\mathrm{mmol}_{\mathrm{CO}_{2}} / \mathrm{g}\right)$ of sample $\mathrm{C}$ as a function of $\mathrm{CO}_{2}$ pressure (atmosphere). 
TGA analysis were performed with wet $\mathrm{CO}_{2}$, see Experimental. Since it is assumed that the slag samples had adsorbed atmospheric $\mathrm{CO}_{2}$ while in open air storage, the samples were preheated to $700{ }^{\circ} \mathrm{C}$ under $\mathrm{Ar}$ atmosphere to desorb any $\mathrm{CO}_{2}$ from constituent carbonates. Once cooled to room temperature, the carrier gas was switched to wet $\mathrm{CO}_{2}$ (caused by passing through $\mathrm{CO}_{2}$ through a water bubbler), which has been observed to maximize $\mathrm{CO}_{2}$ uptake for oxide mixtures $[12,13]$. Once the mass reached a plateau, the sample was heated to $100{ }^{\circ} \mathrm{C}$ to remove any mass gain that may have been caused by water in the wet $\mathrm{CO}_{2}$ flow. The resulting uptake is summarized in Table 3 , and a representative plot is shown in Figure 7.

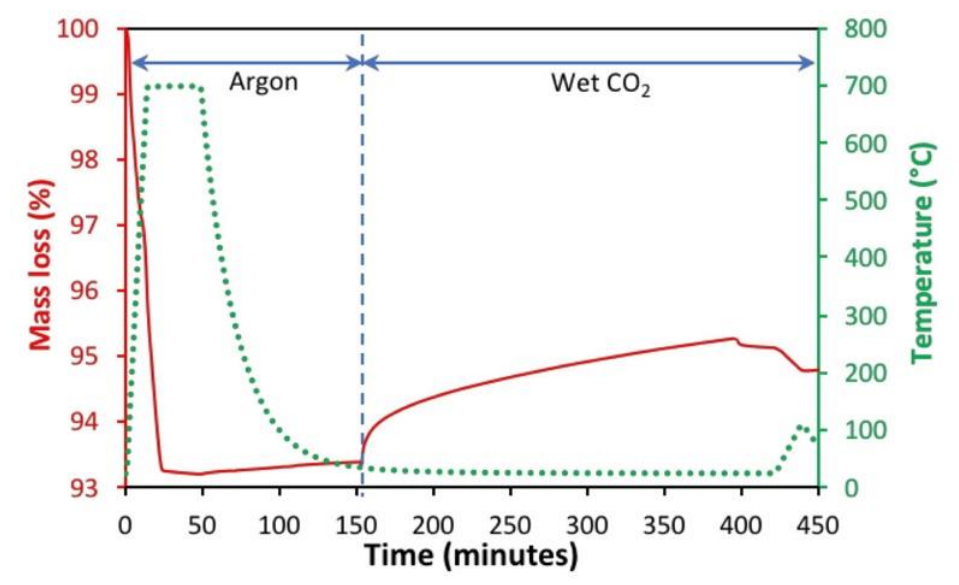

Figure 7 TGA plot showing mass loss $(\%)$ as a function of temperature $\left({ }^{\circ} \mathrm{C}\right)$ plotted against time (minutes) in sample $C$.

\section{Discussion}

The slag morphology shown in Figure 2 is in line with what Yildirim et al. reported with a porphyritic heterogeneous slag texture with visible pockets of free lime [14]. Comparing the samples, it appears that some of the pieces in sample B show a significant rusty brown appearance, suggesting a higher high iron content than observed for the other samples, which is consistent with elemental analysis (Tables 1 and 2). The degree of crystallinity and texture of slag is controlled by the method of cooling. For example, air-cooling, which the samples studied herein have been subjected to, is known to result in a coarse texture [15]. The SEM images reveal the heterogeneous nature of the slag particles, with a coarse morphology associated with fused particles, which is in line with previous reports $[6,15,16]$. The presence of large cavities is observed in Sample A (c.f., Figure 3a). Also present within sample A are large particles (highlighted in Figure 3b), whose composition is consistent with elemental iron, based upon energy dispersive X-ray (EDX) spectroscopy (Figure 4).

Figure 8 shows a plot of the determined elemental composition as determined by XRF (Table 1) versus that obtained from ICP-OES (Table 2), in which it may be seen that the determined composition is essentially independent of method (i.e., the values are on the dashed line that represents an ideal direct relationship). The only sample with outliers is sample $A$, in which the aluminum $\left(\mathrm{Al}_{2} \mathrm{O}_{3}\right)$ content is dramatically higher than the other samples, while the calcium ( $\mathrm{CaO}$ ) content is concomitantly lower. This is indicative of the inhomogeneous nature of the slag since previous reports suggest that the $\mathrm{Al}_{2} \mathrm{O}_{3}$ concentration should be $0.98 \%-6 \%$ [16-21]. However, based 
upon the XRD, the $\mathrm{Al}_{2} \mathrm{O}_{3}$ phase content of sample $\mathrm{A}$ should be lower than $\mathrm{CaCO}_{3}, \mathrm{CaO}$, and $\mathrm{SiO}_{2}$, suggesting that the portion of sample $A$ used for XRF analysis is not as representative as that of Sample $\mathrm{B}$ or $\mathrm{C}$. A high amount of $\mathrm{Al}_{2} \mathrm{O}_{3}$ in cement mortar can affect the viscosity of the cement, directly affecting the pumping characteristics of the cement and the setting characteristics of the cement [22].

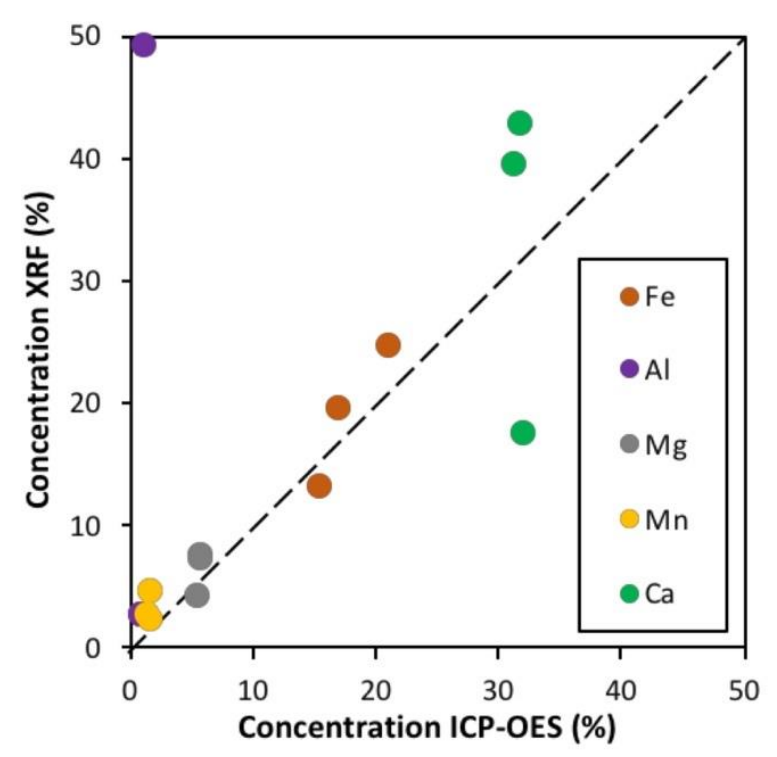

Figure 8 Plot of elemental composition (\%) of basic oxygen steelmaking (BOS) slag as determined by X-ray fluorescence (XRF) versus elemental composition (\%) determined from inductively coupled plasma optical emission spectroscopy (ICP-OES). The dashed line represents an ideal direct correlation between the two methods.

From the data in Tables 1 and 2, it can be seen that the total Fe content of the slag ranges considerably between the slag samples. This concentration is to be expected as it has been observed by several previous studies on the characterization of BOS slag utilizing XRF [23-25]. It has been previously reported that there is a relationship between the average size of the particles and the \% composition [26]; however, in the present case, this is not apparent. The variation in iron content is more likely due to the addition of the iron ore to some samples of molten pig iron in the BOS process to help to cool the molten metal [19]. This may have occurred during the cooling of sample $B$ as in both the XRF and ICP, there is a higher Fe content than samples $A$ and $C$. Higher Fe content causes a material to have a higher hardness so, therefore, may improve the compressive strength of a construction material [27].

The concentration of $\mathrm{CaO}$ is consistent with literature values $18 \%-50 \%[18-20,25,26,28]$ and appears to represent the major phase in all the samples. Juckes observed the chemical composition of a BOS slag sample from Tata Steel, Port Talbot, and reported that the $\mathrm{CaO}$ concentration was $45.83 \%$ [24], which is similar to sample $\mathrm{B}$ and $\mathrm{C}$. The $\mathrm{CaO}: \mathrm{CaCO}_{3}$ ratio, as determined by XRD, is a function of the age of the slag. As produced prior to cooling, it will be decarbonized. However, exposure to atmospheric $\mathrm{CO}_{2}$ upon cooling and storage will convert the $\mathrm{CaO}$ to $\mathrm{CaCO}_{3}$. The calculated basicity ([CaO]/[ $\left.\mathrm{SiO}_{2}\right]$ [18]) of the slag samples is shown in Table 1 and is found to be at the high end of the previously reported range of 0.78-3.4 [25, 29]. High basicity can increase the amount of phosphorus that is removed in dephosphorization as well as enabling the slag to exhibit 
cementitious properties [30, 31]. A high basicity slag can be categorized as more reactive due to the higher free $\mathrm{CaO}$ content and the higher amount of hydraulic activity [30]. The $\mathrm{CaO}$ content should also relate to the $\mathrm{CO}_{2}$ uptake potential of the slags; see below. $\mathrm{CaO}$ and $\mathrm{MgO}$ are susceptible to volume instability, meaning that the slag can swell and change shape on contact with moisture. If the BOS slag is intended for use as aggregate in concrete, this is an unfavorable feature as it could cause catastrophic failure. ASTM C150, which is the standard specification for Portland cement, limits the concentration of $\mathrm{MgO}$ in slag to $<6 \%$, and there is no limit on $\mathrm{CaO}$ content [32]. However, pre-treatment to the slag can be used to mitigate the risk of instability before it is used in cement, for example, letting the slag weather outside [33].

As shown in Table 2 shows the ICP concentrations across all 3 samples for $\mathrm{Mg}$, the values are consistent with each other. They range from 5.38\%-5.60\%, consistent with values found in the literature [22, 34]. The XRF data in Table 1 is not consistent for $\mathrm{MgO}$, as the sample A concentration is significantly less than samples $B$ and $C$. This is in line with the previous observation of the XRF data for sample $\mathrm{A}$ being inaccurate due to the high $\mathrm{Al}_{2} \mathrm{O}_{3}$ content. $\mathrm{MgO}$ has only been characterized as being present in the XRD data for sample $\mathrm{C}$. The $\mathrm{P}_{2} \mathrm{O}_{5}$ concentration found in the samples ranges is within the literature range from $0.2 \%-3.3 \%[14,17,20,21,24]$. It has previously been reported that a higher $\mathrm{P}_{2} \mathrm{O}_{5}$ concentration influences the stability of the dicalcium silicate $\left(\mathrm{C}_{2} \mathrm{~S}, \mathrm{Ca}_{2} \mathrm{SiO}_{4}\right)$ concentration [17]. In the early 1900's steelmaking processes, the concentration of $\mathrm{P}_{2} \mathrm{O}_{5}$ was much higher at about $12-16 \%$, which was a desirable quality for its use as fertilizer [19]. Thus, the present slag is not a potential fertilizer source.

The XRD scan of sample $A$ is of greater signal-to-noise (Figure 5a), consistent with a more crystalline nature. It has been reported in the literature that the presence of iron in samples can cause a noisy XRD spectrum to be produced [35], which is consistent with the XRF and ICP-OES analysis of samples $B$ and $C$ (Tables 1 and 2). An alternative rationalization is the rate of cooling for sample $A$ has been slower than samples $B$ and $C$, without the use of water cooling, which would accelerate the solidification [14].

$\mathrm{SiO}_{2}$ is a major crystalline phase in all three of the samples. In the 5-10 mm particle sized BOS slag sample, the $\mathrm{SiO}_{2}$ is present as two phases, one of which, $\alpha-\mathrm{SiO}_{2}$, is formed upon transformation of $\beta-\mathrm{SiO}_{2}$ at $573{ }^{\circ} \mathrm{C}$ on cooling [36]. Two different iron oxide formations were observed in the XRD analysis; $\mathrm{Fe}_{0.944} \mathrm{O}$ (wüstite) and $\mathrm{Fe}_{0.902} \mathrm{O}$; however, in all three of the samples, the $\mathrm{FeO}$ phases were all observed to be minor crystalline phases, despite the relatively high iron contents. This observation is consistent with prior reports that designated the iron oxide phases as only being "probable" [14, 25, 37, 38].

The presence of calcium silicates in $\mathrm{BOS}$ slag such as dicalcium silicate $\left(\mathrm{Ca}_{2} \mathrm{SiO}_{4}\right)$, tricalcium silicate $\left(\mathrm{Ca}_{3} \mathrm{SiO}_{5}\right)$, and wollastonite $\left(\mathrm{CaSiO}_{3}\right)$ induces $\mathrm{BOS}$ slag to have cementitious properties [18], and as such, for many years, some portion of steelmaking slags have been utilized and recycled in the civil engineering industry as cement, roadbed material, aggregate in concrete and the stabilization of riverbanks [2]. Currently, there is a tremendous pressure on steelmaking plants to reduce their waste that ends up in a landfill. By utilizing these applications, the steelmaking process can limit its environmentally impact.

Several cementitious materials were observed as crystalline phases in samples B, and C. Alite $\left(C_{3} S\right.$ ) was observed to be a major phase in samples $B$ and $C$. In sample $C$, the phase was observed to be the dominant crystalline phase in the sample, while in sample $B$, it was the second most abundant major phase, but $\mathrm{Ca}_{2} \mathrm{O}_{5} \mathrm{Fe}_{2}\left(\mathrm{C}_{2} \mathrm{~F}\right.$, Srebrodol' skite) was also observed to be a major crystalline phase 
in sample $B$. In both samples, $C_{3} S$ is present at a higher content than $C_{2} S$. We have previously shown that the strength development of cements correlates with increasing $C_{3} S / C_{2} S$ ratio [30], thus based upon crystalline phase content, the BOS slags would result in lower time for strength development and a higher compressive strength than those with low $\mathrm{C}_{3} \mathrm{~S} / \mathrm{C}_{2} \mathrm{~S}$ ratio.

Two polymorphs of $C_{2} S$ were present in samples $B$ and $C: \beta-C_{2} S$ (Larnite) and $\gamma-C_{2} S$ [39]. In both cases, there is a higher abundance $\beta-C_{2} S$ than $\gamma-C_{2} S$, which is unusual since $\gamma-C_{2} S$ has been previously observed as a major phase in steelmaking slag $[37,40]$. The conversion from $\beta-C_{2} S$ to $\gamma-C_{2} S$ occurs at lower temperatures, and during that transformation, there is a $10 \%$ increase in volume. This leads to the crystallite formations of $\gamma-\mathrm{C}_{2} \mathrm{~S}$ shattering into dust [41]. It can be said that the dust particles are much smaller than the slag itself. This possibly suggests that during the movement of the slag from the slag cooling pits to the landfill storing site as well as the slags exposure to natural elements such as wind, some of the $\gamma-\mathrm{C}_{2} \mathrm{~S}$ in dust form is lost, hence the lower abundance of it in the slag composition. It has been reported that $\beta-C_{2} S$ absorbs less $\mathrm{CO}_{2}$ than $\gamma-C_{2} S$, but presents a higher compressive strength as a cementitious material [42].

The presence of $\mathrm{Mn}_{2} \mathrm{O}_{3}$ was only observed in the highly crystalline sample $A$. The presence of $\mathrm{Mn}_{2} \mathrm{O}_{3}$ (bixybyite) in BOS slag is not frequent in slag as it is only reported rarely [37]. Although the concentration of manganese was recorded by XRF and ICP in all three of the slag samples; however, crystalline $\mathrm{Mn}_{2} \mathrm{O}_{3}$ was not observed in samples $\mathrm{B}$ and $\mathrm{C}$, possibly because of the many phases that overlap at $2 \theta=33^{\circ}$, making it challenging to identify. The chromium oxide $\mathrm{Cr}_{2} \mathrm{O}_{3}$ was found to be present as a possible minor phase, which is consistent with the ICP analysis. Chromium is added during the steelmaking process to increase the resistance of the steel to corrosion, and the amount added varies from steel plant to steel plant. As chromium has been found to be toxic in the past, the presence of it in the slag is not favorable if the slag is to be used in a marine application, for example [30,37]. To prevent the formation of chromate, it is recommended that the slag is rapidly cooled [30].

As noted above, the presence of $\mathrm{CaO}$ in the slag samples offers potential of $\mathrm{CO}_{2}$ capture/sequestration within a building material. The uptake measured with dry $\mathrm{CO}_{2}$ on the as received slag samples are shown in Table 3. The data for the pressure dependent adsorption may be fitted successfully with the Freundlich isotherm as defined by Equation 1, where $Q_{e}(\mathrm{mmol} / \mathrm{g})$ is the capacity of adsorption of $\mathrm{CO}_{2}$ by the adsorbents, $\mathrm{K}_{\mathrm{f}}$ is the Freundlich isotherm constant $\left(\mathrm{mmol} / \mathrm{g} \cdot \mathrm{atm}^{1 / \mathrm{n}}\right)$, and $\mathrm{n}$ is the heterogeneity factor that represents the deviation of the linearity of the adsorption.

$$
\mathrm{Qe}=\mathrm{K}_{\mathrm{f}}\left(\mathrm{P}_{\mathrm{CO}_{2}}\right)^{\frac{1}{\mathrm{n}}}
$$

Figure 9 shows an example of the plot of $\log \left(Q_{e}\right)$ versus $\log \left(P_{\mathrm{CO} 2}\right)$ from which the Freundlich isotherm constant $\left(\mathrm{K}_{\mathrm{f}}\right)$ and heterogeneity factor $(\mathrm{n})$ is obtained. A similar analysis of each of the data is summarized in Table 4. When the value of $n$ is between 2 and 10 , the adsorbent is considered to have a high adsorption capacity [43]. The Freundlich model [39] is used for systems with a high degree of heterogeneity, where it is assumed that there is an exponential decrease in energy as the coverage of the surface occurs [44]. 


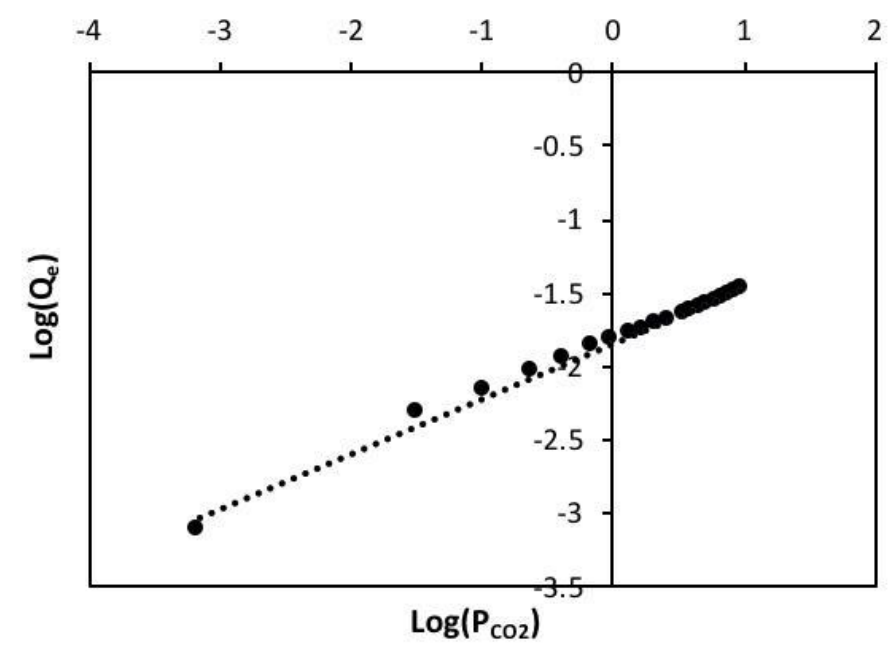

Figure 9 plot of $\log \left(\mathrm{Q}_{\mathrm{e}}\right)$ versus $\log \left(\mathrm{P}_{\mathrm{cO} 2}\right)$ for dry $\mathrm{CO}_{2}$ adsorption by sample $C\left(\mathrm{R}^{2}=0.991\right)$.

Table 4 Calculated Freundlich isotherm constant $\left(\mathrm{K}_{\mathrm{f}}\right)$ and heterogeneity factor $(\mathrm{n})$ for dry $\mathrm{CO}_{2}$ adsorption of basic oxygen steelmaking (BOS) slag determined by gas adsorption.

\begin{tabular}{cccc}
\hline & Sample A & Sample B & Sample C \\
\hline $\mathrm{K}_{\mathrm{f}}\left(\mathrm{mmol} / \mathrm{g} \cdot \mathrm{atm}^{1 / \mathrm{n}}\right)$ & 0.0154 & 0.00367 & 0.0141 \\
$\mathrm{n}$ & 2.206 & 2.286 & 2.668 \\
$\mathrm{R}^{2}$ & 0.995 & 0.989 & 0.991 \\
\hline
\end{tabular}

It has been shown in several previous studies that the amount of $\mathrm{CO}_{2}$ captured when using wet $\mathrm{CO}_{2}$ is significantly more than dry $\mathrm{CO}_{2}[12,13,45,46]$. The moisture in the wet $\mathrm{CO}_{2}$ gas stream allows soluble calcium from phases such as $\mathrm{CaO}, \mathrm{Ca}_{2} \mathrm{SiO}_{4}$, and $\mathrm{Ca}_{3} \mathrm{SiO}_{5}$ to dissolve and create calcium ions, which react with the carbonate ions (formed upon $\mathrm{CO}_{2}$ dissolution) to form $\mathrm{CaCO}_{3}$ [47]. As such, the uptake of wet $\mathrm{CO}_{2}$ is significantly higher in all samples than dry $\mathrm{CO}_{2}$ (Table 3). Therefore, as the iSorb analysis does not use wet $\mathrm{CO}_{2}$ and instead uses dry $\mathrm{CO}_{2}$, it did not perform as well as the TGA adsorption. Sample $\mathrm{C}$ was seen to absorb the most $\mathrm{CO}_{2}$ during the wet $\mathrm{CO}_{2}$ TGA experiment, and ICP-OES analysis (Table 1 ) suggests that sample $\mathrm{C}$ contains significantly more $\mathrm{CaO}$ and $\mathrm{SiO}_{2}$ as compared to the other samples. In both ICP and XRF measurements, sample B was found to have less $\mathrm{Ca}$ and $\mathrm{Si}$ than sample $\mathrm{C}$, so this is possibly why sample $\mathrm{B}$ absorbed less $\mathrm{CO}_{2}$ in both TGA and iSorb measurements.

\section{Conclusions}

We have analyzed samples of BOS slags from Tata Port Talbot Steelworks for their elemental and phase composition. Based upon this analysis, we conclude that those samples with the higher levels of $\mathrm{CaO}$ and calcium silicates (samples $\mathrm{B}$ and $\mathrm{C}$ ) would be suitable as cementitious materials, in particular after adsorption of atmospheric $\mathrm{CO}_{2}$ and forming $\mathrm{CaCO}_{3}[12,13]$. The presence of the major phases needed for steelmaking slag to exhibit cementitious properties (i.e., $C_{3} S, C_{2} S, C_{2} F$, and $\mathrm{C}_{4} \mathrm{AF}$ ) are present in BOS slag samples, suggesting they may be used to produce carbon-negative and cement-free construction blocks by using their use as an aggregate. In addition, although an 
apparent anomaly, the low $\mathrm{CaO}$ content of sample $\mathrm{A}$ would also make it suitable for a marine application, as the risk of volume instability is mitigated with a lower $\mathrm{CaO}$ concentration [2].

\section{Acknowledgments}

The AIM facility provided access to XRD and we would like to acknowledge the assistance provided by Swansea University College of Engineering AIM Facility, which was funded in part by the EPSRC (EP/M028267/1), the European Regional Development Fund through the Welsh Government (80708) and the Ser Solar project via Welsh Government.

\section{Author Contributions}

Lucy V. Fisher: Conceptualization; Methodology; Formal analysis; Investigation; Writing - Original Draft; Investigation; Data Curation; Andrew R Barron: Conceptualization; Resources; Writing Review \& Editing; Supervision; Project administration; Funding acquisition.

\section{Funding}

Financial support was provided by Materials and Manufacturing Academy (M2A) that has been made possible through funding from the European Social Fund via the Welsh Government, the Engineering and Physical Sciences Research Council (EPSRC), and Tata Steel Europe. Additional support is provided by the Reducing Industrial Carbon Emissions (RICE) operations funded by the Welsh European Funding Office (WEFO) through the Welsh Government, the Welsh Government Sêr Cymru Chair Program, and the Robert A. Welch Foundation (C-0002).

\section{Competing Interests}

The authors have declared that no competing interests exist.

\section{References}

1. Shen H, Forssberg E. An overview of recovery of metals from slags. Waste Manag. 2003; 23: 933-949.

2. Fisher LV, Barron AR. The recycling and reuse of steelmaking slags - a review. Resour Conserv Recycl. 2019; 146: 244-255.

3. Liu C, Guo M, Pandelaers L, Blanpain B, Huang S. Stabilization of free lime in BOF slag by melting and solidification in air. Metall Mater Trans B. 2016; 47: 3237-3240.

4. Takahashi T, Yabuta K. New applications for iron and steelmaking slag. NKK Tech Rev. 2002; 87: 38-44.

5. Mehta PK. Pozzolanic and cementitious by-products in concrete-another look. ACl Symp Publ. 1989; 114: 1-44.

6. Carvalho SZ, Vernilli F, Almeida B, Demarco M, Silva SN. The recycling effect of BOF slag in the Portland cement properties. Resour Conserv Recycl. 2017; 127: 216-220.

7. Portland Cement Concrete Materials. US Department of Transportation Federal Highway Administration; 1995 [citied date 2021 February 4]. Available from: https://www.fhwa.dot.gov/pavement/pubs/013683.pdf. 
8. Dong Q, Wang GT, Chen XQ, Tan J, Gu XY. Recycling of steel slag aggregate in portland cement concrete: An overview. J Clean Prod. 2021; 282: 124447.

9. Pomaro B, Gramegna F, Cherubini R, De Nadal V, Salomoni V, Faleschini F. Gamma-ray shielding properties of heavyweight concrete with electric arc furnace slag as aggregate: An experimental and numerical study. Constr Build Mater. 2019; 200: 188-197.

10. Polettini A, Pomi R, Stramazzo A. $\mathrm{CO}_{2}$ sequestration through aqueous accelerated carbonation of BOF slag: A factorial study of parameters effects. J Environ Manage. 2016; 167: 185-195.

11. Port Talbot Steelworks. The Environmental Permitting (England \& Wales) Regulations 2010. Neath, UK: Natural Resources Wales; 2010; Permit number EPR/BL7108IM.

12. Lupu C, Jackson KL, Bard S, Rusakova I, Barron AR. Control over cement setting through the use of chemically modified fly ash. Adv Eng Mater. 2006; 8: 576-580.

13. Lupu C, Jackson KL, Bard S, Barron AR. Water, acid and calcium carbonate pretreatment of fly ash: The effect on setting of cement-fly ash mixtures. Ind Eng Chem Res. 2007; 46: 8018-8025.

14. Yildirim IZ, Prezzi M. Chemical, mineralogical, and morphological properties of steel slag. Adv Civ Eng. 2011; 2011: 463638.

15. Carvalho SZ, Vernilli F, Almeida B, Oliveira MD, Silva SN. Reducing environmental impacts: The use of basic oxygen furnace slag in portland cement. J Clean Prod. 2018; 172: 385-390.

16. Yildirim IZ, Prezzi M. Steel slag: Chemistry, mineralogy, and morphology. proceedings of the IFCEE 2015; 2015 Mar 17-21; San Antonio, Texas. Reston: American Society of Civil Engineers.

17. Motz H, Geiseler J. Products of steel slags an opportunity to save natural resources. Waste Manag. 2001; 21: 285-293.

18. Shi CJ. Steel slag - its production, processing, characteristics, and cementitious properties. J Mater Civ Eng. 2004; 16: 230-236.

19. Juckes LM. The volume stability of modern steelmaking slags. Miner Process Extr Metall. 2003; 112: 177-197.

20. Das B, Prakash S, Reddy PS, Misra VN. An overview of utilization of slag and sludge from steel industries. Resour Conserv Recycl. 2007; 50: 40-57.

21. Shen $\mathrm{DH}, \mathrm{Wu} \mathrm{CM}, \mathrm{Du} \mathrm{JC}$. Laboratory investigation of basic oxygen furnace slag for substitution of aggregate in porous asphalt mixture. Constr Build Mater. 2009; 23: 453-461.

22. Pan SY, Chung TC, Ho CC, Hou CJ, Chen YH, Chiang PC. $\mathrm{CO}_{2}$ mineralization and utilization using steel slag for establishing a waste-to-resource supply chain. Sci Rep. 2017; 7: 17227.

23. Bonvin D. X-ray fluorescence spectrometry in the iron and steel industry. In Encyclopedia of Analytical Chemistry. Hoboken: John Wiley and Sons Inc; 2006.

24. Asaoka S, Okamura H, Morisawa R, Murakami H, Fukushi K, Okajima T, et al. Removal of hydrogen sulfide using carbonated steel slag. Chem Eng J. 2013; 228: 843-849.

25. Vlcek J, Tomkova V, Ovcacikova H, Ovcacik F, Topinkova M. Slags from steel production: Properties and their utilization. Metalurgija. 2013; 52: 329-333.

26. Zhang TS, Yu QJ, Wei JX, Li JX, Zhang PP. Preparation of high performance blended cements and reclamation of iron concentrate from basic oxygen furnace steel slag. Resour Conserv Recycl. 2011; 56: 48-55.

27. Pan SY, Adhikari R, Chen YH, Li P, Chiang PC. Integrated and innovative steel slag utilization for iron reclamation, green material production and $\mathrm{CO}_{2}$ fixation via accelerated carbonation. J Clean Prod. 2016; 137: 617-631. 
28. Jia RQ, Liu JX. Simulated experiment study of factors influencing the hydration activity of $\mathrm{f}-\mathrm{CaO}$ in basic oxygen furnace slag. Adv Mater Sci Eng. 2016; 2016: 7529382.

29. Řeháčková L, Rosypalová S, Dudek R, Kukutschová J, Dobrovská J. Effect of $\mathrm{CaO} / \mathrm{SiO}_{2}$ ratio on viscosity and structure of slag. Metalurgija. 2015; 54: 455-458.

30. Shi CJ. Characteristics and cementitious properties of ladle slag fines from steel production. Cem Concr Res. 2002; 32: 459-462.

31. Barker KJ, Paules JR, Rymarchyk N, Jancosko RM. Oxygen steelmaking furnace mechanical description and maintenance considerations. The AISE Steel Foundation. Steel making and refining volume. Pittsburgh: AISE, 1998. p.431-474.

32. Li YM, Pei SL, Pan SY, Chiang PC, Lu CY, Ouyang T. Carbonation and utilization of basic oxygen furnace slag coupled with concentrated water from electrodeionization. J $\mathrm{CO}_{2}$ Utili. 2018; 25: 46-55.

33. Jiang Y, Ling TC, Shi CJ, Pan SY. Characteristics of steel slags and their use in cement and concrete - A review. Resour Conserv Recy. 2018; 136: 187-197.

34. Liu J, Guo RH. Applications of steel slag powder and steel slag aggregate in ultra-high performance concrete. Adv Civ Eng. 2018; 2018: 1-8.

35. Mandile AJ, Hutton AC. Quantitative X-ray diffraction analysis of mineral and organic phases in organic-rich rocks. Int J Coal Geol. 1995; 28: 51-69.

36. Wright AF, Lehmann MS. The structure of quartz at 25 and $590{ }^{\circ} \mathrm{C}$ determined by neutron diffraction. J Solid State Chem. 1981; 36: 371-380.

37. Tossavainen M, Engstrom F, Yang Q, Menad N, Lidstrom Larsson M, Bjorkman B. Characteristics of steel slag under different cooling conditions. Waste Manag. 2007; 27: 1335-1244.

38. Blanco I, Molle P, Sáenz de Miera LE, Ansola G. Basic oxygen furnace steel slag aggregates for phosphorus treatment: Evaluation of its potential use as a substrate in constructed wetlands. Water Res. 2015; 89: 355-365.

39. Freundlich H. Über die adsorption in lösungen. Z Phys Chem. 1907; 57: 385-470.

40. Minato $D$. Mechanism of carbonation process of $\mathrm{Y}-\mathrm{C}_{2} \mathrm{~S}$ and its effect on strength development. Sapporo, Hokkaido: School of Engineering Hokkaido University; 2021.

41. Edwards CL, Morgan R, Norman L, Funkhouser GP, Barron AR. Correlation of cement performance property measurements with $\mathrm{C}_{3} \mathrm{~S} / \mathrm{C}_{2} \mathrm{~S}$ ratio determined by solid state ${ }^{29} \mathrm{Si} \mathrm{NMR}$ measurements. Ind Eng Chem Res. 2008; 47: 5456-5463.

42. Chang J, Fang YF, Shang XP. The role of $\beta-C_{2} S$ and $Y-C_{2} S$ in carbon capture and strength development. Mater Struct. 2016; 49: 4417-4424.

43. Brdar $M$, Šćiban $M$, Takači A, Došenović T. Comparison of two and three parameters adsorption isotherm for $\mathrm{Cr}(\mathrm{VI})$ onto Kraft lignin. Chem Eng J. 2012; 183: 108-111.

44. Barka N, Ouzaouit K, Abdennouri M, Makhfouk ME. Dried prickly pear cactus (opuntia ficus indica) cladodes as a low-cost and eco-friendly biosorbent for dyes removal from aqueous solutions. J Taiwan Inst Chem Eng. 2013; 44: 52-60.

45. Sarperi L, Surbrenat A, Kerihuel A, Chazarenc $F$. The use of an industrial by-product as a sorbent to remove $\mathrm{CO}_{2}$ and $\mathrm{H}_{2} \mathrm{~S}$ from biogas. J Environ Chem Eng. 2014; 2: 1207-1213.

46. Reddy K, Chetri J, Kumar G, Grubb D. Effect of basic oxygen furnace slag type on carbon dioxide sequestration from landfill gas emissions. Waste Manag. 2019; 85: 425-436. 
47. Yilmaz D, Lassabatere L, Deneele D, Angulo-Jaramillo R, Legret M. Influence of carbonation on the microstructure and hydraulic properties of a basic oxygen furnace slag. Vadose Zone J. 2013; 12: 1-15.

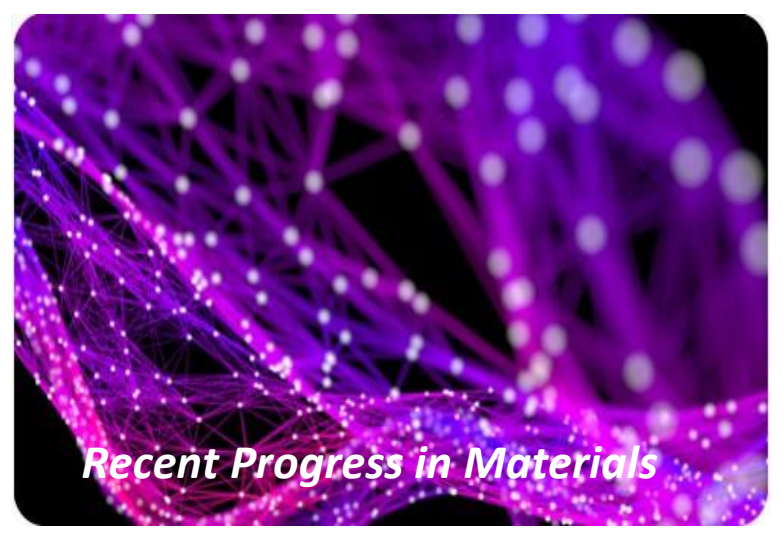

Enjoy Recent Progress in Materials by:

1. Submitting a manuscript

2. Joining in volunteer reviewer bank

3. Joining Editorial Board

4. Guest editing a special issue

For more details, please visit:

http://www.lidsen.com/journals/rpm 